\title{
RAGAM HIAS PADA KOMPLEKS MAKAM SUNAN DRAJAT
}

\author{
Oleh: Novida Abbas
}

I

Proses kedatangan dan penyebaran Islam di Indonesia, khususnya di Jawa, telah banyak dibicarakan oleh para ahli. Bukti pertama mengenai eksistensi Islam di Jawa adalah nisan kubur Fatimah binti Maimun bin Hibatullah di Leran (Gresik) yang berangka tahun $475 \mathrm{H}$ atau $1082 \mathrm{M}$ (Uka Tjandrasasmita, 1976: 2). Selanjutnya Islam dikembangkan melalui proses perdagangan dan perkawinan. Lambat laun timbullah kerajaan-kerajaan yang bercorak Islam menggantikan kerajaan-kerajaan Hindu, seperti misalnya Demak, Banten dan Cirebon.

Selain melalui perdagangan, perkawinan dan politik, tidak kalah pentingnya peranan sembilan orang wali dalam penyebaran agama Islam di Jawa. Kesembilan orang wali itu, yang terkenal dengan sebutan Wali Sanga, adalah Sunan Ampel, Sunan Giri, Sunan Bonang, Sunan Drajat, Sunan Muria, Syekh Siti Jenar, Sunan Kudus, Sunan Kalijaga dan Sunan Gunung Jati. Pokok pembicaraan dalam tulisan ini adalah ragam hias pada salah satu makam wali tersebut, yaitu makam Sunan Drajat. Makam Sunan Drajat sampai saat ini masih dipergunakan sebagai tempat berziarah dan masih dikeramatkan, seperti halnya makam para wali lainnya.

Sunan Drajat adalah salah seorang putra Sunan Ampel. Sebelum bergelar Sunan Drajat ia bernama Masih Munat (C. Israr, 1978: 159). Menurut keterangan yang diperoleh dari juru kunci makam, Sunan Drajat menyebarkan agama Islam dari pesantrennya yang terdapat di daerah Drajat, oleh karena itu ia memperoleh gelar sebagai Sunan Drajat. Diceritakan pula bahwa Sunan Drajat mendirikan sebuah masjid yang terletak di sebelah timur kompleks makam. Saat ini masjid tersebut hanya merupakan segundukan batu yang ditumbuhi semak belukar.

\section{II}

Kompleks makam Sunan Drajat terletak di Drajat, kec. Paciran, kab. Lamongan, Jawa Timur. Kompleks ini disebutkan pertama kali oleh J. Kne bel pada tahun 1907 (J. Knebel, 1908: 261-262). Kemudian disebutkan pula dalam laporan seorang pengawas bangunan mengenai sebuah peninggal an kepurbakalaan yang terdapat di Drajat, sebelah timur Sendang Duwur (Stutterheim, 1940: 10). Kompleks ini dipugar untuk pertama kali pada awal tahun 1941 (Stutterheim, 1949: 39).

Kompleks makam Sunan Drajat terdiri dari tiga teras (Foto: 1). Pada teras ketiga yang terletak paling belakang dan paling tinggi terdapat cungkub makam Sunan Drajat. Cungkub tersebut merupakan sebuah bangunan tembok. Bagian dalam cungkub terbagi menjadi tiga bagian, yaitu bagian depan, tengah dan belakang: 


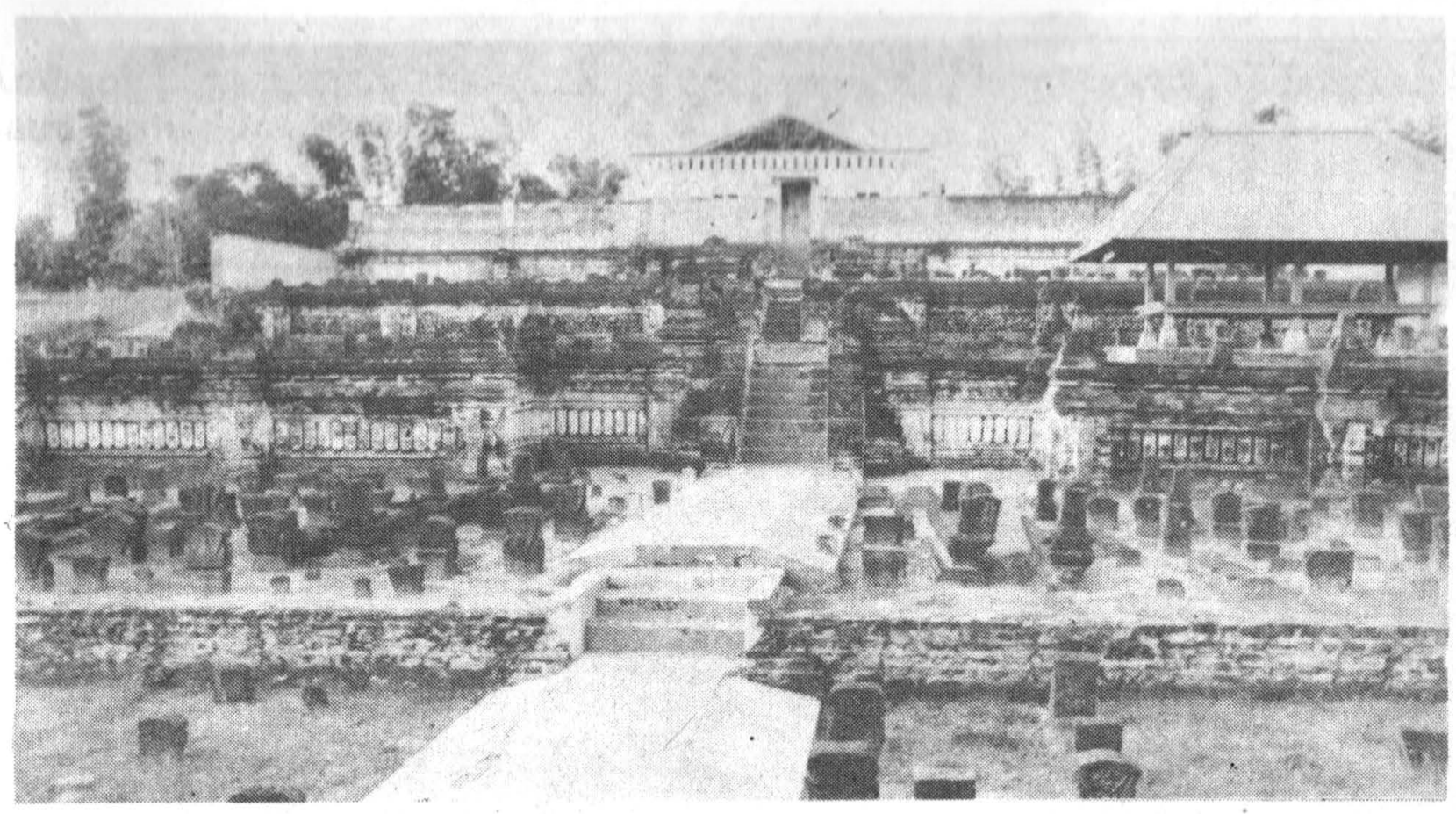

Foto 1: Kompleks makam Sunan Drajat.

Pada bagian depan terdapat makam-makam para kerabat Sunan Drajat. Antara bagian depan dan tengah terdapat sebuah sekat yang terbuat dari kayu. Pada bagian tengah terdapat enam buah makam, yaitu tiga makam putra Sunan Drajat dan tiga makam menantunya. Pada bagian belakang terdapat sebuah cungkub yang terbuat dari kayu. Di dalam cungkub ini terdapat makam Sunan Drajat dan istrinya.

Pada beberapa makam, dinding penyekat dan dinding cungkub kayu terdapat beberapa ragam hias yang akan dibicarakan di bawah ini.

\section{Makam.}

Ragam hias yang akan dibicarakan terutama yang terdapat pada ma. kam yang berada di dalam cungkub. Sebagian besar makam-makam itu sederhana, baik dalam bentuk maupun hiasan. Nisan pada makam-makam tersebut berbentuk kurawal yang sebagian besar polos. Beberapa nisan misalnya yang terdapat pada makam istri dan putra Sunan Drajat, mempunyai ragam hias medalion dan roset.

Medalion yang terdapat pada nisan putra Sunan Drajat, bagian tengahnya dihiasi dengan tulisan dalam huruf Arab, sedang yang terdapat pada nisan istri Sunan Drajat berbentuk kurawal dan polos.

Jirat pada makam-makam tersebut sebagian besar bertingkat tiga. Pada sisi-sisi dan sudut-sudut jirat terdapat hiasan tumpal.

\section{Dinding penyekat.}

Dinding penyekat yang terbuat dari kayu terbagi dalam panel-panel berbentuk segi empat. Di tengah-tengah terdapat sebuah pintu. Dinding di sisi kiri dan kanan pintu tersebut masing-masing terbagi menjadi enam buah panel, yaitu tiga di bagian atas dan tiga di bagian bawah (Foto: 2). 


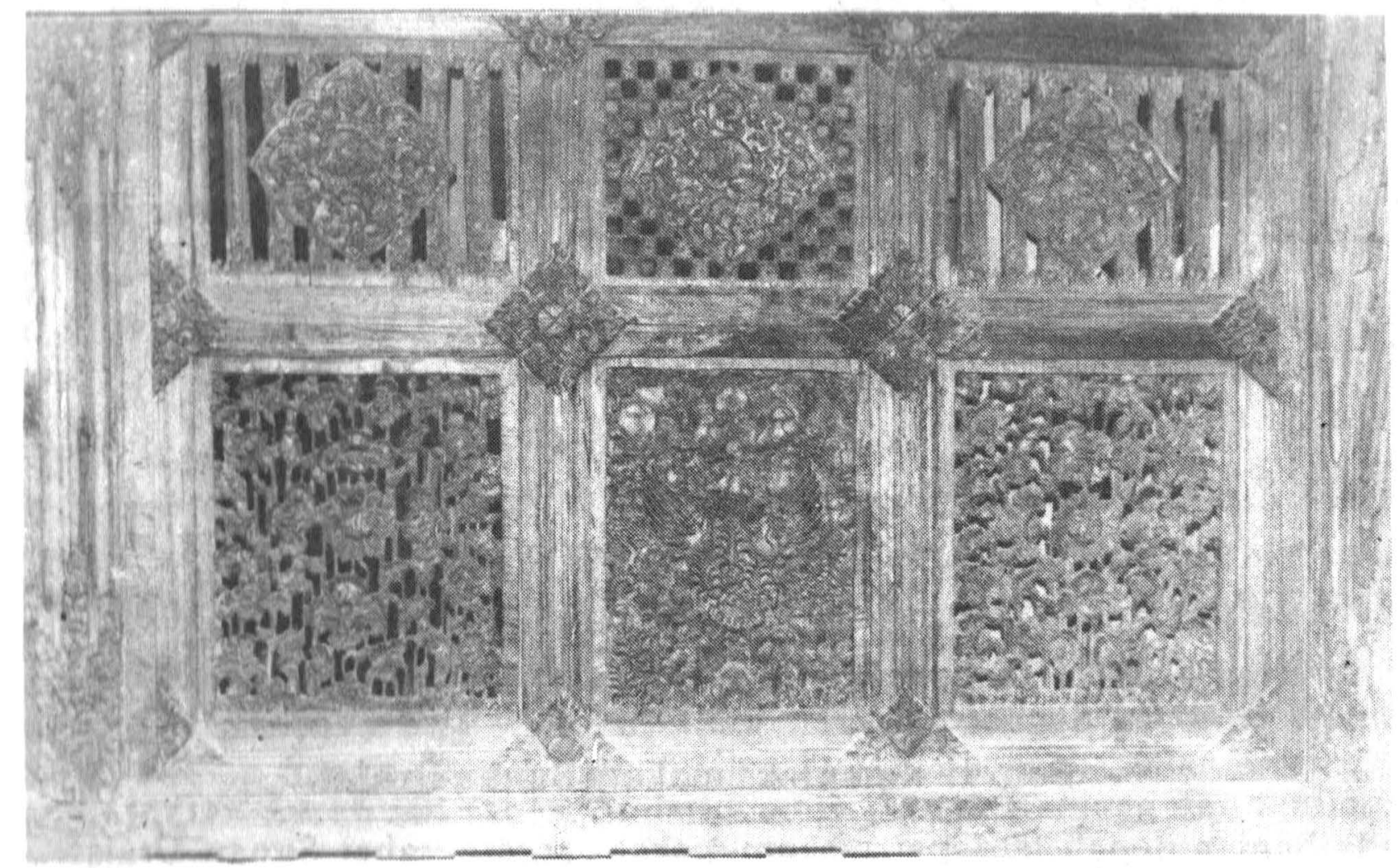

Foto 2: Panel-panel pada dinding penyekat.

Ragam hias pada panel-panel di sebelah kiri sama dengan panel-panel di sebelah kanan. Lima diantaranya merupakan ukiran kerawang dengan motif tumbuh-tumbuhan, sedangkan yang sebuah mempunyai hiasan sayap, gunung dan tumbuh-tumbuhan.

Pada ambang pintu terdapat dua buah arca singa yang distilir dengan motif sulur-suluran (Foto: 3 ).

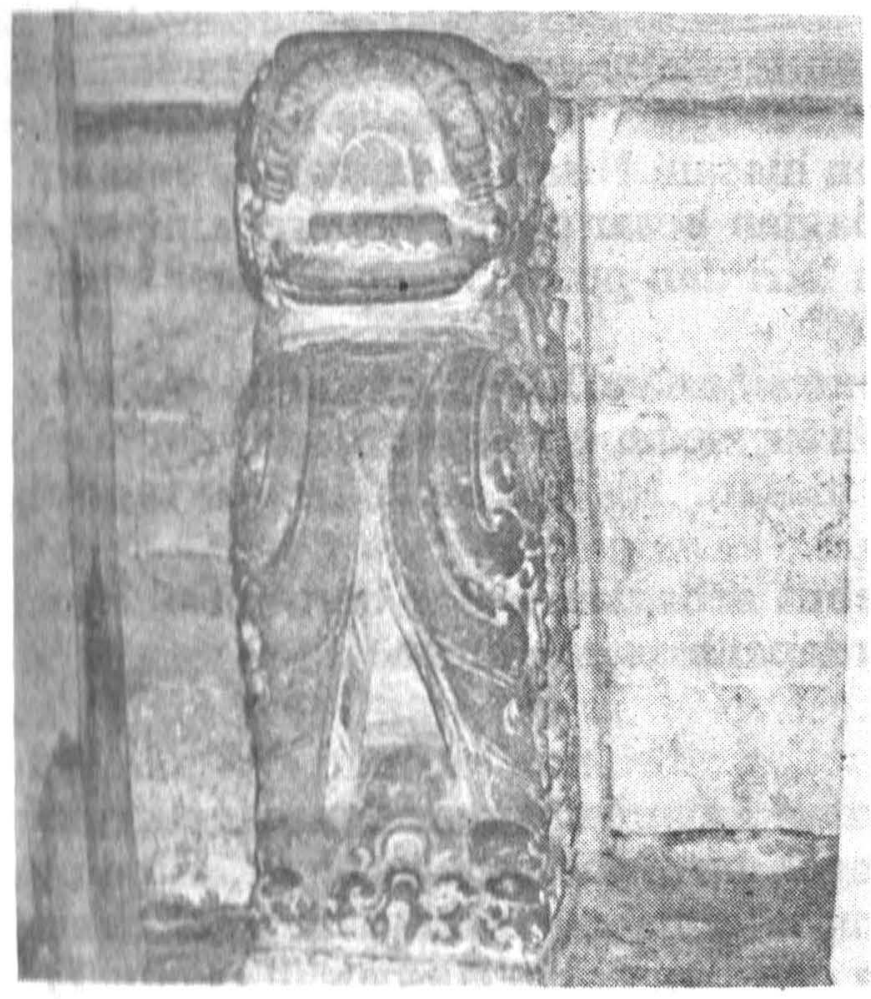

Foto 3:

Motif singa pada ambang pintu. 
Ambang pintu bagian bawah dihias dengan motif pinggir awan, sedangkan daun pintu tidak berhias.

\section{Dinding cungkub kayu.}

Dinding cungkub kayu bagian depan juga terbagi menjadi panelpanel segi empat dan masing-masing mempunyai hiasan. Dinding sisi kiri, kanan dan belakang tidak berhias. Pada panel-panel di dinding depan terdapat ragam hias berupa bingka cermm yang diisi dengan motif pemandangan, bunga teratai dan tumbuh-tumbuhan lainnya (Foto: 4). Di luar bingkai cermin tersebut, sebagai pengisi bidang digunakan motif pinggir awan dan tumbuh-tumbuhan.

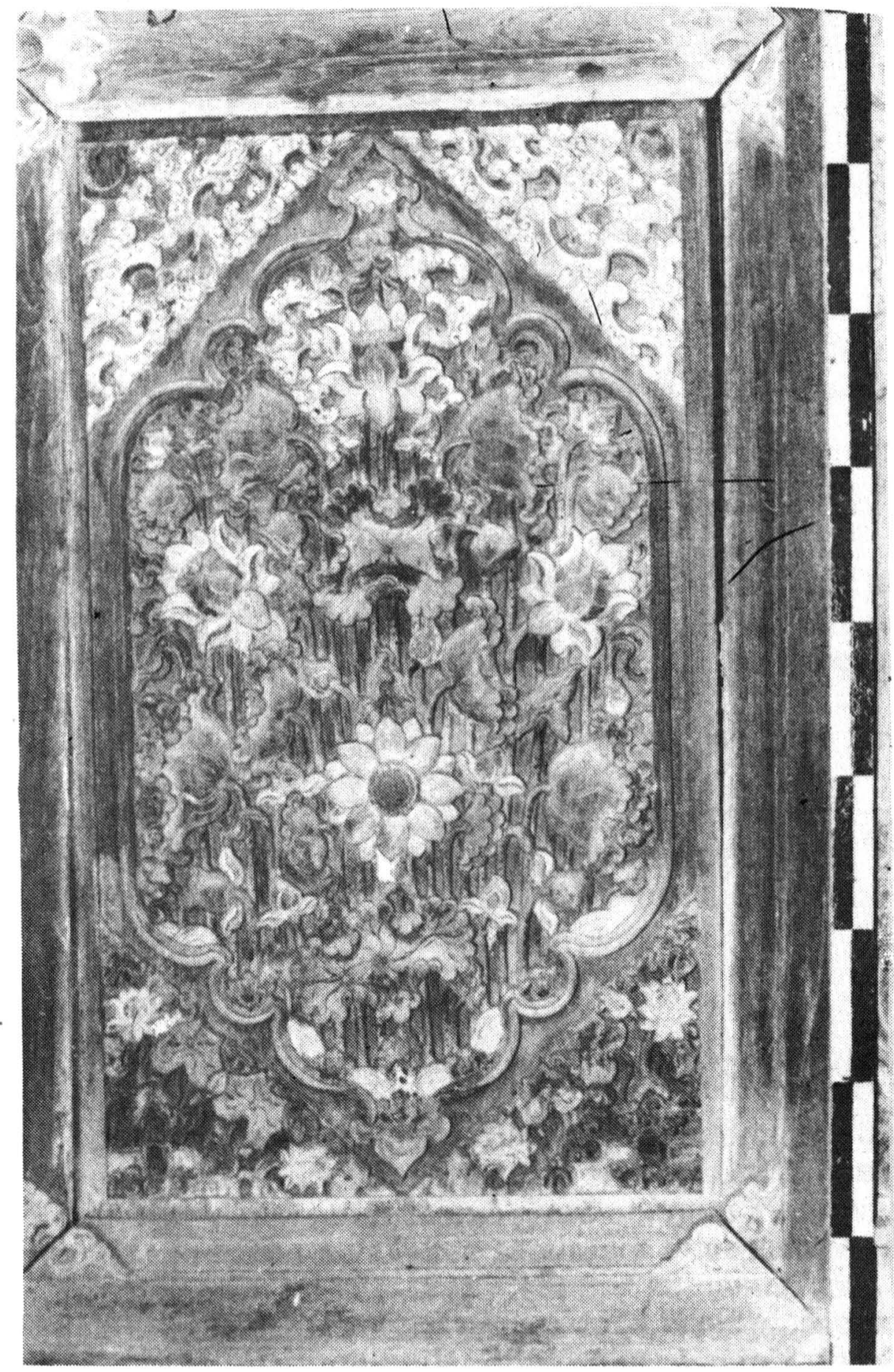

Foto 4: Motif teratai pada salah satu panel. 
lir.

Pada pintu masuk cungkub terdapat dua buah arca singa yang disti-

Kedua arca singa tersebut telah rusak. Daun pintu mempunyai ukiran dengan motif tumbuh-tumbuhan, pinggir awan dan di bagian tengah terdapat motif sayap (Foto: 5). Pada ambang pintu bagian atas terdapat sebuah sengkalan yang dibaca oleh Stutterheim sebagai mulya guna panca waktu atau 1531 Caka: 1609 M (Stutterheim, 1949: 39). Menurut pembacaan Knebel sengkala tersebut berbunyi leng pinrapat ginawe jalma atau 1449 Caka: 1527 M (J. Knebel, 1908: 262).

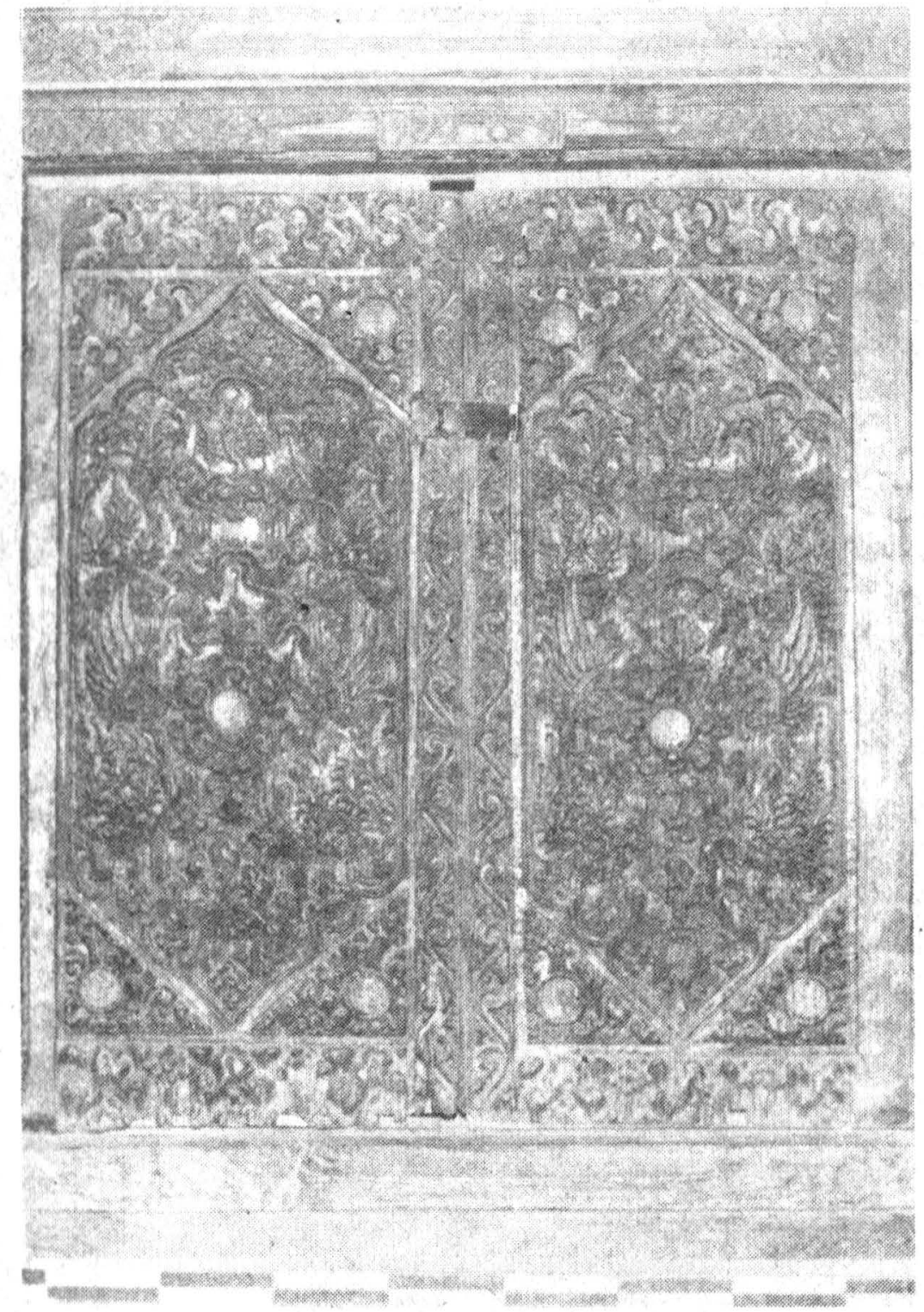

Foto 5: Pintu cungkub makam Sunan Drajat.

Selain pada ambang pintu cungkub tersebut, terdapat pula sebuah sengkalan pada dinding barat cungkub batu. Sengkalan itu berupa pahatan yang menggambarkan gelombang dan di sudut kanan atas terdapat sebuah anak panah. Stutterheim membaca sengkalan tersebut sebagai segera pinanah ing....... atau 454?: 1454 Caka: 1532M (Stutterheim, 1949: 39). Knebel membacanya sebagai segara mumbul pinanah tunggil atau 1504 Caka: 1582M (J. Knebel, 1908: 262). 
Dari pengamatan terhadap ragam hias yang terdapat pada kompleks makam Sunan Drajat, ternyata dijumpai beberapa jenis ragam hias, yaitu ragam hias geometris, tumbuh-tumbuhan, binatang dan ragam hias lainnya.

\section{Ragam hias geometris.}

Ragam hias geometris berupa pinggir awæn, tumpal dan medalion. Motif pinggir awan asalnya adalah dari motif pinggir meander yang banyak dijumpai dalam kesenian Cina. Motif pingeir awan banyak digunakan pada kesenian Cirebon dan biasanya dipakai untuk menyatakan awan (Van der Hoop, 1949: 56). Pada kompleks makam Sunan Drajat, motif pinggir awan dijumpai pada bingkai-bingkai di bawah maupun di atas panel, sehingga kemungkinan motif ini berfungsi sebagai pengisi bidang.

Motif tumpal dan medalion yang terdapat pada beberapa jirat dan nisan kemungkinan juga berfungsi sebagai pengisi bidang. Motif tumpal telah dikenal sejak jaman prasejarah, misalnya yang digunakan sebagai hiasan pada nekara-nekara dan gerabah (Van der Hoop, 1949: 24). Selanjut nya motif ini banyak dijumpai pada masa kebudayaan Hindu, Islam dan bahkan masih digunakan sampai sekarang.

\section{Ragam hias tumbuh-tumbuhan.}

Ragam hias tumbuh-tumbuhan mulai muncul pada masa kebudayaan Hindu. Dari sejumlah motif tumbuh-tumbuhan yang terdapat di kompleks makam ini, yang dapat dikenali adalah bunga teratai. Menurut Van der Hoop, bunga 'teratai terdiri atas tiga jenis, yaitu:

1. Teratai merah atau nelumbium speciosum, dengan ciri-ciri daun bunganya lebar dan tepi daun bergelombang.

2. Teratai biru atau nympheen stellata, yaitu daun bunganya tidak lebar, bunga tidak pernah digambarkan terbuka sama sekali, tepi daunnya tidak bergelombang atau sedikit bergelombang.

3. Teratai putih atau nymphee lotos, dengan ciri-ciri daun bunga lebar tetapi runcing-runcing dan tepi daun tidak bergelombang (Van der Hoop, 1949: 258).

Motif bunga teratai yang terdapat di kompleks makam ini adalah bunga teratai merah, karena daun bunganya lebar serta tepi daunnya bergelombang.

\section{Ragam hias binatang.}

Ragam hias binatang yang terdapat di sini adalah singa. Singa atau felis loo adalah jenis binatang yangु tidak terdapat di pulau Jawa (S. Kadarsan et al., 1977: 6). Motif singa mulai dikenal bersamaan dengan masuknya kebudayaan Hindu. Pada kesenian Hindu di Jawa, motif singa merupa 
kan simbol dari aspek ball atau sebagai penjaga dari pengaruh-pengaruh jahat (Timbul Haryono, 1980: 49). Pada beberapa kekunaan Islam yang berupa kompleks makam, terutama yang terdapat di daerah pantai utara, singa biasanya dijumpai pada ambang pintu cungkub. Kemungkinan motif singa pada kekunaan Islam berfungsi sebagai simbol penjaga yang melindungi kompleks makam dari pengaruh-pengaruh jahat.

Selain motif singa, dijumpai pula motif sayap.

Motif sayap sebenarnya dapat dikaitkan dengan motif burung. Burung sudah dikenal sejak jaman prasejarah dan biasanya digunakan untuk melambangkan roh orang yang telah meninggal (Van der Hoop, 1949: 166). Motif sayap sering dikaitkan dengan polepaaan. Motif sayap yang terdapat di sini kemungkinan digunakan sebagai lambang pelepasan jiwa dari raganya.

Ragam hias lain.

Ragam hias lain yang terdapat di kompleks ini adalah pemandangan dan binglad cermin. Motif pemandangan dijumpai dalam kesenian Hindu maupun Islam. Pemandangan yang terdapat pada dinding cungkub makam Sunan Drajat melukiskan gunung-gunung dan tumbuh-tumbuhan. Gunung sendiri pada masa kebudayaan pra Islam dianggap sebagai tempat bersemayam para dewa ataupun roh-roh.

Selain itu banyak ditemui bingkal cermin pada panel-panel kayu. Yang dimaksud dengan bingka cermin adalah bentuk segi empat yang salah satu atau kedua sisinya berbentuk kurawal (Van der Hoop, 1949: 314).

Biasanya bingkal cermm ini tidak berdiri sendiri, melainkan berfungsi sebagai bingkai bagi motif-motif lainnya. Bagian tengah bingkai cermin ini diisi dengan motif tumbuh-tumbuhan, sulur-suluran dan lain-lain.

\section{IV}

Dari uraian mengenai ragam hias yang terdapat di kompleks makam Sunan Drajat, terlihat bahwa ragam hias di sini mempunyai beberapa arti dan fungsi. Selain sebagai unsur dekoratif, ragam hias itu juga berfungsi sebagai pengisi bidang, misalnya beberapa ragam hias geometris dan tumbuh-tumbuhan yang terdapat pada ambang pintu bagian bawah dan bingkai panel. Selain itu, beberapa motif tertentu tampaknya disesuaikan dengan sifat bangunannya. Motif-motif itu misalnya motif sayap, singa dan gunung, mempunyai arti simbolis yang sesuai dengan sifat bangunan itu sendiri, yaitu kompleks makam. Sayap melambangkan pelepasan, singa melambangkan pelindung dari unsur-unsur jahat dan gunung melambangkan tempat bersemayam roh-roh.

Kepustakaan:

Haryono, Timbul, 1980

"Singa dalam kesenian Hindu di Jawa Tengah", Seri Penerbitan Balai Arkeologi. Yogyakarta Th. I No. 1. 
Hoop, A.N.J. Th. a. Th. van der,

1949 Indonesische Siermotieven, K.B.G.

Israr, $\mathrm{C}$.

1978

Sejarah Kesenian Islam 2, Jakarta, Bulan Bintang.

Kadarsan, S. et al. "Fauna asing pada relief candi-candi di pulau 1977

Knebel, J.

1908 Jawa", MISI jilid VII No. 2, Jakarta, Bhratara.

Rapporten van de Commissie in Nederlandsch Indie 1907.

Stutterheim, W.F., $\quad$ Oudheidkundig Verslag 1939, Batavia, Kon. Druk1940 kerij de Unie.

1949 Oudheidkundig Verslàg 1941-1942, Bandoeng, A.C. Nix \& Co.

Uka Tjandrasasmita, "Sepintas mengenai peninggalan kepurbakalaan 1976 Islam di pesisir utara Jawk", Aspek-aspek Arkeologi Indonesia No. 3, Jakarta, Karya Nusantara. 